\title{
Who Walks the Walk and Talks the Talk? Understanding What Influences Sustainability Behaviour in Business and Leisure Travellers
}

\author{
Rachel Dodds ${ }^{1}$ and Mark Robert Holmes ${ }^{2, *(D)}$ \\ 1 Ted Rogers School of Hospitality and Tourism Management, Ryerson University, \\ Toronto, ON M5B 2K3, Canada; r2dodds@ryerson.ca \\ 2 School of Hospitality, Food and Tourism Management, Gordon S. Lang School of Business and Economics, \\ University of Guelph, Guelph, ON N1G 2W1, Canada \\ * Correspondence: mholme07@uoguelph.ca; Tel.: +1-519-824-4120 (ext. 56309)
}

Citation: Dodds, R.; Holmes, M.R. Who Walks the Walk and Talks the Talk? Understanding What Influences Sustainability Behaviour in Business and Leisure Travellers. Sustainability 2022, 14, 883. https:// doi.org/10.3390/su14020883

Academic Editors: Choong-Ki Lee and Sung-Eun Kang

Received: 30 November 2021

Accepted: 11 January 2022

Published: 13 January 2022

Publisher's Note: MDPI stays neutral with regard to jurisdictional claims in published maps and institutional affiliations.

Copyright: (C) 2022 by the authors. Licensee MDPI, Basel, Switzerland. This article is an open access article distributed under the terms and conditions of the Creative Commons Attribution (CC BY) license (https:// creativecommons.org/licenses/by/ $4.0 /)$.

\begin{abstract}
While there is considerable research into what drives tourists to travel sustainably, little has been done to examine business travellers and how they differ from leisure travellers. The purpose of this paper is to fill this gap by looking to understand these differences and what drives them. Specifically, this paper looked to understand the influence that demographics, travel characteristics, and everyday behaviour (pro-ecological actions, frugal consumption patterns, and altruistic behaviours) have on sustainable travel behaviour, and if these influences held true for both business and leisure travellers. To facilitate this investigation, a quantitative study of 869 Canadian travellers in March of 2020 was undertaken. This research found that demographics and travel characteristics to contribute to the prediction of sustainable travel behaviour, but the greatest prediction power came from everyday behaviour. Beyond confirming that everyday behaviour is still the greatest indicator of sustainable travel domestically or abroad, this research found that this influence does not change whether the travel is for business or leisure.
\end{abstract}

Keywords: sustainable travel; behaviour; pro-ecological behaviour; frugality; altruism; business travel

\section{Introduction}

Tourism's impact on the environment and the potential for sustainable travel are timely points of discussion and investigation $[1,2]$ as adopting more sustainable practices contributes to the essential Sustainable Development Goals (SDGs). Often, 'sustainable tourists' have been recognized as the most desirable tourists due to their more environmentally friendly behaviours, greater yield or more amenable behaviour [3-7]. For example, these 'sustainable tourists' are more likely than other segments to satisfy the entirety of the "triple bottom line" [6] (p. 176) by aiding social initiatives, the local environment, and supporting the local economy.

Regardless of whether a tourist is, or is not, concerned about the environment or community, researchers have noted that there are challenges faced by tourists in translating their attitudes into sustainable behaviour while travelling [2,8-13]. Beyond Madrigal [14] finding that personal values are a significant predictor of travel behaviour, Han et al. [15] found pro-environmental habits at home to be a strong predictor of pro-environmental behaviours (PEBs). Holmes et al. [5] also found this to be true with other sustainability behaviours while on vacation. Liu et al. [2], however, found an unclear relationship between habits at home and habits while travelling and suggested a possible explanation is that vacation is an escape from everyday routine. Taken together, this set of literature demonstrates inconsistencies in findings surrounding the divergence in behaviour between what is done at home and when travelling.

There is also a gap in the literature when examining leisure versus business traveller behaviour. While leisure travellers have begun to increase their uptake of sustainable travel 
opportunities, business travellers have yet to see significant growth in this area $[16,17]$. Limited research has investigated daily behaviours of consumers compared to what effect these have (if any) on their behaviours when business travellers are engaged in tourism; further, the results have been mixed and behaviours are often context specific $[2,13,18]$.

It is, therefore, unclear from the literature what is understood to be a 'sustainable tourist', and few studies provide a clear connection between a tourist's home behaviour regarding the environment, and whether similar behaviour is transposed while travelling. A possible reason for this ambiguity may be that sustainable consumers are considered across the entire population of tourists, rather than a distinguished and identifiable segment, such as for leisure and business, or sustainable traveller and typical traveller [5]). As other researchers have highlighted, intentions and attitudes are not sufficient for explaining behaviour $[8,10]$. Therefore, this study aims to determine whether predictors of behaviour versus action hold true and also determine if there is a clear distinction between leisure versus business travellers.

\section{Literature Review}

There are a variety of explanations for why the inconsistency between attitude and behaviour within travel exists. Hibbert et al. [19] propose that this attitude-behaviour gap has increased where behaviour at home and abroad do not align as individuals are progressively becoming more mobile. These authors note that different self's manifest contingent on the situation, which could explain the discrepancy between an individual's attitude and behaviour at home and on vacation. Such a contingency was also found by Liu et al. [2] who found that greater degrees of 'daily green behaviours' moderated a greater propensity to conduct such behaviours while traveling, supporting a notion that one's habits can influence the attitude-behaviour gap even across a different context. They also found a relationship between subjective norm and those with less 'daily green behaviour', suggesting that, for some travellers, an environment that encourages pro-environmental behaviours (PEBs) may be necessary to keep a greener-self manifested while travelling. These, and other studies (see, e.g., [20]) suggest that the attitude-behaviour gap is still a challenge, and that it is an obstacle for educating tourists and changing their environmental behaviours. If the potential pro-sustainable behaviour of tourists is to be understood, the way forward will require a deeper investigation into travellers' attitudes and their actual behaviours.

\subsection{Pro-Environmental Behaviours at Home and Travelling}

Discussions around pro-ecological behaviour (PEB) are becoming increasingly common in the tourism sphere of inquiry, and while the definition of PEBs tend to differ slightly between studies, the commonality between most of them is that they are behaviours that either mitigate an individual's impact on the environment or positively impact the environment [21]. PEBs almost unanimously include the environment in their measures of sustainability (see, e.g., Liu et al. [2]; Whitmarsh and O'Neill, [18]); however, some literature also expand the sustainability discussion of PEBs to include environmental as well as social considerations [5,22-24]. Other papers on PEB tend to measure a participant's engagement in different daily behaviours often through self-reports [18,23-29]. Some even take this a step further, studying the connections between PEBs at home and PEBs while traveling $[2,5,12,15,30,31]$.

Corral-Verdugo et al. [26] include numerous sustainability behaviours including proecological actions, frugal consumption patterns, and altruistic behaviours. These components represent broader categories of sustainable behaviours aimed at protecting both natural and the human resources in the socio-physical environment. Holmes et al. [5] expanded on Corral-Verdugo et al.'s [26] work and notably demonstrated that these three components have explanatory value with respect to tourists' sustainable behaviour while travelling. 


\subsection{Leisure vs. Business Traveller}

In addition to attitudes versus behaviour, a common shortcoming in the literature is the lack of discussion about the business traveller segment and their behaviour while at home or traveling. PEB literature appears to, perhaps unintentionally, exclude PEBs done for work while traveling; however, Young et al. [32] provide potentially valuable insights in their review, proposing that environmental attitudes are not necessarily a prerequisite for PEBs while working. Instead, "once employees know why and how to switch off machines at the end of shifts. They may do so even without having pro-environmental attitudes, because of the work structure, systems, culture and rewards for doing so" (p. 700). As 'context' has been suggested as an important influence on PEBs (i.e., [2,13]), this could be a contributor to why daily PEBs at home do not appear to transpose when travelling. Further, from what Young et al. [32] highlight, one's PEBs at work may follow different expectations than one's behaviours at home. Together, the lack of literature on PEBs at home and PEBs while traveling for business and for leisure necessitates a greater investigation.

\subsection{Frugality, Altruism and Egoism in Sustainable Travel Behaviour}

There also appears to be an absence of literature on the connection between frugality and PEBs in business travellers. Juvan and Dolnicar [33], found that travellers of the older segment (over the age of 30 years old) found travel to be a necessary task for work even while acknowledging this behaviour's negative environmental impact. Extrapolating from Young et al.'s [32] review, workers may simply follow their employer's PEBs in policies and practices. Intuitively, there is an obvious motive for frugality in business travel: an employer could require that business travel be as cost-efficient as possible, and thus frugality would be emphasized. However, frugality may not be a concern as a business may just require the business trip to be undertaken regardless of the cost. In either case, there appears to be a gap in the understanding of the PEBs done during business travel. Altogether, equitable use of products and intentionally limiting personal product consumption are central themes of frugal behaviour [5]. Other studies have found that frugality tends to take second place to indulgence while on vacation [9], which could suggest an important dichotomy between leisure and business travel making.

In contrast to egoistic motives, altruism is the characteristics of actively behaving in ways to benefit other human beings [34,35]. Altruism's connection to helping those outside the self, advances the sustainability cause because choices are made with consideration of their impact on other people; thus, it is core to pro-ecological motivation. According to Schultz [36], altruistic individuals can be characterized by a greater predilection to making sacrifices as well as possessing a greater perception of control; therefore, to an altruistic individual, pro-ecologically behaviour would be seen as a necessary action. Robust support across many studies has shown that greater degree of altruism and altruistic behaviours result in a greater incidence of PEBs at home [2,22-24,26,29,31,37], as well as when traveling and on vacation $[2,5,12,13]$. Conversely, egoistic travel attitudes resulted in less environmentally sustainable behaviour as was found in a study by Canavan [38]. Oliver et al. [12] also found that egoistic values related to a diminished ecological outlook. However, egoism under a broad definition of personal/utility gain was found to promote (rather than hamper) PEB while touring, so long as it was more useful to the individual [13].

The three hypotheses this paper looks to examine are as follows:

Hypothesis 1 (H1). Business and leisure travellers will differ in their sustainable travel behaviour.

Hypothesis 2 (H2). The relationship between frugality and sustainable travel behaviour will be significant for the leisure traveller.

Hypothesis 3 (H3). The relationship between frugality and sustainable travel behaviour will not be significant for the business traveller. 
Hypothesis 4 (H4). The relationship between altruism and sustainable travel behaviour will be positively significant for the leisure traveller.

Hypothesis 5 (H5). The relationship between altruism and sustainable travel behaviour will be positively significant for the business traveller.

\section{Materials and Methods}

To determine sustainability behaviours as well as the different between business versus leisure travellers, this research employed structured surveys of a panel population. The population was asked questions pertaining to demographics, everyday behaviour, typical reason for travel (business versus leisure), and sustainable travel behaviour. Everyday behaviour was captured drawing on three separate constructs developed by Corral-Verdugo et al. [26,39]. The three constructs are comprised of questions pertaining to pro-ecological behaviour (e.g., "I wait until I have a full load before doing laundry"), frugality (e.g., I wear the same clothing from past season), and altruism (e.g., "I help elders or the handicapped cross the street"). Typical reason for travel was measured by asking the participants if they typically travel for business and leisure, and then to respond to questions pertaining to their choice. To capture sustainable travel behaviour, questions such as "Tourists have a responsibility to do what they can to protect the environment," were asked, derived from the work of Juvan and Dolnicar [33] and Passafaro et al. [40]. All constructs were captured using 5-point Likert-type scales as used by Corral Verdugo et al. [39].

The survey developed for this study was administered by the company Dynata through the online survey tool Qualtrics. The research protocol was approved by the research ethics board at Ryerson University. A total of 2886 Canadian travellers completed the survey between mid-February and mid-March of 2020. Screening questions were used to ensure those panel participants were Canadian travellers, over the age of 18, who had traveled at least once in the past year. After cleaning the data set $(80 \%$ completion rate and duplication of response), 869 respondents were retained for analysis.

This research looked to understand if those who typically travel for business are significantly different at home and travelling than those who travel for leisure. To facilitate this understanding, two different methods of analysis are employed. First, Mann-Whitney U tests were run to investigate if demographics, as well as every day and travel behaviours of those who travel are significantly different from those who travel for leisure. Second, a regression was employed to understand the influence that is typically travelling for business or leisure has on travelling sustainably, when demographics were controlled for.

\section{Results}

The respondents to the survey were slightly heavily male (57.6\%) and heavily Canadian born $(82.4 \%)$. There was a fairly even split of age ranges and education levels, with a higher frequency of $\$ 100,000$ + income level respondents (see Table 1a,b). In regard to travel characteristics, one-third of respondents travel alone (32.1\%), one-third travel with their partner/spouse (31.5\%), and the remainder travelling with friends, colleagues, or family. Close to half (45.7\%) of travellers travel in all seasons. More than half (54.3\%) of travellers sometimes revisit the same destination, and there is a fairly even split of travellers typically travelling for business $(54.1 \%)$ and leisure $(45.9 \%)$.

Beyond looking at the overall frequencies, this study looked to see if the demographic profiles, everyday behaviour, and sustainable travel behaviour of travellers differ based on their typical travel for business or leisure. To test these differences, given the nonparametric nature of some of the variables, Mann-Whitney U tests were undertaken. As can be seen in Table 1a,b below, business travellers are more commonly men, well educated, with higher incomes. While those who travel for business are more likely to be altruistic, leisure travellers are more likely to be frugal. When it comes to pro-ecological behaviour, business 
travellers are more likely to point out unecological behaviour to someone, talk with friends about environmental problems, and buy products in refillable packages; on the other hand, those who typically travel for leisure are more likely to collect and recycle used paper, not buy prepared foods, and not use insecticides (see Table $2 \mathrm{a}-\mathrm{c}$ ). Looking at past sustainable travel behaviour, those who typically travel for business are more likely to travel sustainably (see Table 3). (Those who typically travel for leisure are likely to walk the walk, those who typically travel for business are more likely to walk the walk and talk the talk.) This finding supports research Hypothesis 1, which proposed that business and leisure travellers will differ in their sustainable travel behaviour. This could be linked to the companies' environmental travel policy (i.e., paying for carbon offset), and their desire to consume the local culture (i.e., adapting dress policy, speaking the language, eating at local restaurants).

Table 1. (a): Descriptive Statistics of Demographics and Travel Characteristics and Differences between Business and Leisure Travellers. (b): Descriptive Statistics of Travel Characteristics and Differences between Business and Leisure Travellers.

a: Descriptive Statistics of Demographics and Travel Characteristics and Differences between Business and Leisure Travellers.

$\begin{array}{ccccccc}\text { Variable } & \mathbf{N} & \text { Mean } & \text { Business } & \text { Leisure } & \mathbf{Z} & \text { Sig. } \\ \text { Female } & 869 & 0.424 & 0.321 & 0.544 & -6.614 & 0.000 \\ \text { Canadian Born } & 868 & 0.824 & 0.851 & 0.792 & -2.263 & 0.024 \\ 1928 \text { to } 1945 & 869 & 0.020 & 0.015 & 0.025 & -1.078 & 0.281 \\ 1946 \text { to } 1964 & 869 & 0.265 & 0.243 & 0.291 & -1.603 & 0.109 \\ 1965 \text { to } 1980 & 869 & 0.340 & 0.357 & 0.318 & -1.214 & 0.225 \\ 1981 \text { to } 1996 & 869 & 0.308 & 0.343 & 0.268 & -2.365 & 0.018 \\ \text { 1997 to 2020 } & 869 & 0.068 & 0.043 & 0.098 & -3.221 & 0.001 \\ \text { High School or Less } & 869 & 0.205 & 0.138 & 0.283 & -5.272 & 0.000 \\ \text { College Diploma } & 869 & 0.230 & 0.196 & 0.271 & -2.614 & 0.009 \\ \text { University Degree } & 869 & 0.349 & 0.383 & 0.308 & -2.302 & 0.021 \\ \text { Graduate Degree } & 869 & 0.216 & 0.283 & 0.138 & -5.175 & 0.000 \\ <\$ 30,000 & 869 & 0.162 & 0.094 & 0.243 & -5.953 & 0.000 \\ \text { \$30,000-\$49,999 } & 869 & 0.153 & 0.115 & 0.198 & -3.389 & 0.001 \\ \text { \$50,000-\$69,999 } & 869 & 0.170 & 0.164 & 0.178 & -0.551 & 0.581 \\ \text { \$70,000-\$99,999 } & 869 & 0.175 & 0.194 & 0.153 & -1.574 & 0.115 \\ \$ 100,000-\$ 149,999 & 869 & 0.253 & 0.313 & 0.183 & -4.383 & 0.000 \\ \text { \$150,000+ } & 869 & 0.086 & 0.121 & 0.045 & -3.982 & 0.000\end{array}$

b: Descriptive Statistics of Travel Characteristics and Differences between Business and Leisure Travellers.

\begin{tabular}{cccccccc}
\hline \multicolumn{1}{c}{ Variable } & $\mathbf{N}$ & Mean & Business & Leisure & Z & Sig. \\
& Alone & 868 & 0.321 & 0.486 & 0.128 & -11.259 & 0.000 \\
Travelling & Partner/Spouse & 868 & 0.315 & 0.186 & 0.466 & -8.870 & 0.000 \\
Partners & Family & 868 & 0.199 & 0.105 & 0.311 & -7.578 & 0.000 \\
& Friends & 868 & 0.062 & 0.038 & 0.090 & -3.150 & 0.002 \\
& Colleagues & 868 & 0.099 & 0.181 & 0.003 & -8.779 & 0.000 \\
& Other & 868 & 0.004 & 0.004 & 0.003 & -0.440 & 0.660 \\
\hline \multirow{2}{*}{ Travelling } & Winter & 869 & 0.134 & 0.094 & 0.181 & -3.749 & 0.000 \\
Seasons & Spring & 869 & 0.091 & 0.106 & 0.073 & -1.721 & 0.085 \\
& Summer & 869 & 0.259 & 0.226 & 0.298 & -2.437 & 0.015 \\
& Fall & 869 & 0.060 & 0.036 & 0.088 & -3.191 & 0.001 \\
& All Seasons & 869 & 0.457 & 0.538 & 0.361 & -5.228 & 0.000 \\
\hline Repeat & Repeat Never & 869 & 0.295 & 0.223 & 0.378 & -4.993 & 0.000 \\
Visitation & Repeat & 869 & 0.543 & 0.581 & 0.499 & -2.420 & 0.016 \\
& Sometimes & & & & & & \\
& Repeat & 869 & 0.158 & 0.192 & 0.118 & -2.969 & 0.003 \\
\hline
\end{tabular}


Table 1. Cont.

\begin{tabular}{|c|c|c|c|c|c|c|c|}
\hline \multicolumn{8}{|c|}{$\begin{array}{l}\text { b: Descriptive Statistics of Travel Characteristics and Differences between Business and } \\
\text { Leisure Travellers. }\end{array}$} \\
\hline \multirow{3}{*}{$\begin{array}{l}\text { Frequency of } \\
\text { Travel }\end{array}$} & ble & $\mathbf{N}$ & Mean & Business & Leisure & $\mathbf{Z}$ & Sig. \\
\hline & $\begin{array}{l}\text { Domestic } \\
\text { Travel }\end{array}$ & 822 & 9.690 & 12.623 & 5.981 & -11.619 & 0.000 \\
\hline & $\begin{array}{l}\text { International } \\
\text { Travel }\end{array}$ & 749 & 8.840 & 11.022 & 6.243 & -7.417 & 0.000 \\
\hline Typically & Business & 869 & 0.541 & & & & \\
\hline Travel for & Leisure & 869 & 0.459 & & & & \\
\hline
\end{tabular}

Table 2. (a): Everyday Behaviours Descriptive Statistics and Differences between Business and Leisure Travellers. (b): Pro-Ecological Behaviour Descriptive Statistics and Differences between Business and Leisure Travellers. (c): Frugality Descriptive Statistics and Differences between Business and Leisure Travellers.

\begin{tabular}{|c|c|c|c|c|c|c|}
\hline \multicolumn{7}{|c|}{$\begin{array}{l}\text { a: Everyday Behaviours Descriptive Statistics and Differences between Business and } \\
\text { Leisure Travellers. }\end{array}$} \\
\hline Variable & $\mathbf{N}$ & Mean & Business & Leisure & $\mathrm{Z}$ & Sig. \\
\hline $\begin{array}{l}\text { Donate clothing to the } \\
\text { less fortunate }\end{array}$ & 868 & 3.603 & 3.629 & 3.571 & -0.864 & 0.387 \\
\hline $\begin{array}{l}\text { Assist a person in need on } \\
\text { the street }\end{array}$ & 867 & 3.068 & 3.133 & 2.993 & -2.033 & 0.042 \\
\hline $\begin{array}{l}\text { Contribute financially } \\
\text { such as Red Cross }\end{array}$ & 867 & 3.190 & 3.345 & 3.008 & -4.724 & 0.000 \\
\hline $\begin{array}{l}\text { Visit the sick at } \\
\text { hospitals/homes }\end{array}$ & 867 & 2.238 & 2.444 & 1.995 & -5.264 & 0.000 \\
\hline Help elders or the & & & & & & \\
\hline $\begin{array}{c}\text { handicapped crossing } \\
\text { the street }\end{array}$ & 867 & 2.904 & 2.987 & 2.807 & -2.366 & 0.018 \\
\hline $\begin{array}{l}\text { Guide people asking } \\
\text { for directions }\end{array}$ & 868 & 3.672 & 3.706 & 3.631 & -1.026 & 0.305 \\
\hline $\begin{array}{c}\text { Provide some money to } \\
\text { the homeless }\end{array}$ & 867 & 2.630 & 2.799 & 2.431 & -4.447 & 0.000 \\
\hline $\begin{array}{l}\text { Participates in fund } \\
\text { collection rallies }\end{array}$ & 868 & 2.864 & 3.105 & 2.582 & -6.658 & 0.000 \\
\hline $\begin{array}{c}\text { Donate blood } \\
\text { when required }\end{array}$ & 864 & 2.265 & 2.585 & 1.889 & -7.505 & 0.000 \\
\hline $\begin{array}{l}\text { Cooperate with } \\
\text { colleagues }\end{array}$ & 867 & 3.803 & 3.949 & 3.632 & -3.233 & 0.001 \\
\hline \multicolumn{7}{|c|}{$\begin{array}{l}\text { b: Pro-Ecological Behaviour Descriptive Statistics and Differences between Business and } \\
\text { Leisure Travellers. }\end{array}$} \\
\hline Variable & $\mathbf{N}$ & Mean & Business & Leisure & $\mathbf{Z}$ & Sig. \\
\hline $\begin{array}{l}\text { Wait until I have a full } \\
\text { load before doing laundry }\end{array}$ & 866 & 4.013 & 3.981 & 4.050 & -1.771 & 0.077 \\
\hline $\begin{array}{l}\text { Drive on highway at } \\
\text { speeds under } 100 \mathrm{kph}\end{array}$ & 868 & 2.712 & 2.840 & 2.561 & -3.297 & 0.001 \\
\hline $\begin{array}{l}\text { Collect and recycle } \\
\text { used paper }\end{array}$ & 867 & 4.085 & 3.985 & 4.203 & -3.646 & 0.000 \\
\hline $\begin{array}{l}\text { Point out unecological } \\
\text { behaviour to someone }\end{array}$ & 867 & 2.706 & 2.836 & 2.553 & -3.366 & 0.001 \\
\hline $\begin{array}{l}\text { Do not buy prepared } \\
\text { food (AI) }\end{array}$ & 868 & 3.371 & 3.256 & 3.506 & -3.527 & 0.000 \\
\hline $\begin{array}{l}\text { Buy products in } \\
\text { refillable packages }\end{array}$ & 865 & 2.903 & 2.968 & 2.827 & -2.003 & 0.045 \\
\hline Buy seasonal produce & 869 & 3.593 & 3.619 & 3.561 & -0.721 & 0.471 \\
\hline
\end{tabular}


Table 2. Cont.

\begin{tabular}{|c|c|c|c|c|c|c|}
\hline \multicolumn{7}{|c|}{$\begin{array}{l}\text { b: Pro-Ecological Behaviour Descriptive Statistics and Differences between Business and } \\
\text { Leisure Travellers. }\end{array}$} \\
\hline Variable & $\mathbf{N}$ & Mean & Business & Leisure & $\mathbf{Z}$ & Sig. \\
\hline $\begin{array}{l}\text { Do not use clothes } \\
\text { dryer (AI) }\end{array}$ & 866 & 2.163 & 2.177 & 2.146 & -0.785 & 0.433 \\
\hline $\begin{array}{c}\text { Read about } \\
\text { environmental issues }\end{array}$ & 868 & 3.183 & 3.243 & 3.113 & -1.698 & 0.090 \\
\hline $\begin{array}{l}\text { Pre Ecological } \\
\text { Behaviour-Talk with } \\
\text { friends about } \\
\text { environmental problems }\end{array}$ & 863 & 2.936 & 3.034 & 2.820 & -2.791 & 0.005 \\
\hline $\begin{array}{l}\text { Do not use chemical } \\
\text { insecticides (AI) }\end{array}$ & 867 & 3.961 & 3.734 & 4.229 & -6.325 & 0.000 \\
\hline $\begin{array}{l}\text { Turn down air } \\
\text { conditioning when } \\
\text { leaving place }\end{array}$ & 868 & 3.771 & 3.815 & 3.719 & -0.369 & 0.712 \\
\hline $\begin{array}{l}\text { Look for ways to } \\
\text { reuse things }\end{array}$ & 867 & 3.788 & 3.778 & 3.799 & -0.523 & 0.601 \\
\hline $\begin{array}{l}\text { Encourage friends and } \\
\text { family to recycle }\end{array}$ & 863 & 3.588 & 3.568 & 3.610 & -0.793 & 0.428 \\
\hline $\begin{array}{l}\text { Conserve gasoline by } \\
\text { walking or bicycling }\end{array}$ & 865 & 3.121 & 3.139 & 3.101 & -0.512 & 0.609 \\
\hline \multicolumn{7}{|c|}{ c: Frugality Descriptive Statistics and Differences between Business and Leisure Travellers. } \\
\hline Variable & $\mathbf{N}$ & Mean & Business & Leisure & $\mathbf{Z}$ & Sig. \\
\hline $\begin{array}{l}\text { Do not buy a new car if } \\
\text { old one is still functional }\end{array}$ & 867 & 3.807 & 3.783 & 3.836 & -1.498 & 0.134 \\
\hline $\begin{array}{l}\text { Wear the same clothing } \\
\text { from a past season }\end{array}$ & 867 & 4.228 & 4.134 & 4.340 & -3.132 & 0.002 \\
\hline Do not buy jewelry & 867 & 2.194 & 2.307 & 2.060 & -3.313 & 0.001 \\
\hline $\begin{array}{l}\text { Do not buy lots of } \\
\text { shoes (AI) }\end{array}$ & 867 & 3.897 & 3.729 & 4.096 & -4.472 & 0.000 \\
\hline $\begin{array}{l}\text { Do not buy more food } \\
\text { than needed }(A I)\end{array}$ & 865 & 3.595 & 3.446 & 3.773 & -4.389 & 0.000 \\
\hline $\begin{array}{l}\text { Do not use earnings for } \\
\text { buying clothing (AI) }\end{array}$ & 867 & 4.178 & 3.979 & 4.412 & -5.373 & 0.000 \\
\hline Always eat meals at home & 867 & 3.611 & 3.557 & 3.675 & -2.007 & 0.045 \\
\hline Rather walk than drive & 865 & 2.784 & 2.836 & 2.722 & -1.790 & 0.073 \\
\hline $\begin{array}{l}\text { Reuse notebooks } \\
\text { and papers }\end{array}$ & 862 & 3.399 & 3.400 & 3.398 & -0.174 & 0.862 \\
\hline $\begin{array}{l}\text { Live lightly even when } \\
\text { affording luxuries }\end{array}$ & 866 & 3.495 & 3.473 & 3.521 & -0.667 & 0.505 \\
\hline
\end{tabular}

Table 3. Past Sustainable Travel Behaviour Descriptive Statistics and Differences between Business and Leisure Travellers.

\begin{tabular}{ccccccc}
\hline Variable & $\mathbf{N}$ & Mean & Business & Leisure & $\mathbf{Z}$ & Sig. \\
\hline Locally owned accommodations & 866 & 2.686 & 2.716 & 2.651 & -0.649 & 0.516 \\
Locally grown food and/or drink & 868 & 3.083 & 3.021 & 3.155 & -1.486 & 0.137 \\
$\quad$ Chain food (e.g., McDonalds) & 868 & 2.493 & 2.670 & 2.286 & -4.562 & 0.000 \\
$\begin{array}{c}\text { Purchased Locally made arts and crafts } \\
\text { Look up a company's environmental or } \\
\quad \text { fair-trade policy }\end{array}$ & 862 & 2.643 & 2.556 & 2.745 & -2.208 & 0.027 \\
$\begin{array}{c}\text { Walk or cycle instead of taking motorized } \\
\text { transportation at the destination (taxi or renting } \\
\text { a car) }\end{array}$ & 866 & 2.211 & 2.381 & 2.013 & -3.708 & 0.000 \\
& & & & & \\
\end{tabular}


Table 3. Cont.

\begin{tabular}{|c|c|c|c|c|c|c|}
\hline Variable & $\mathbf{N}$ & Mean & Business & Leisure & $\mathbf{Z}$ & Sig. \\
\hline Avoid renting a private car & 864 & 2.236 & 2.607 & 1.798 & -8.765 & 0.000 \\
\hline $\begin{array}{l}\text { Opt for a different destination that did not need } \\
\text { flying to }\end{array}$ & 863 & 2.596 & 2.630 & 2.554 & -0.894 & 0.371 \\
\hline $\begin{array}{l}\text { Purchase carbon offsets to mitigate your } \\
\text { carbon footprint }\end{array}$ & 861 & 1.979 & 2.178 & 1.744 & -5.008 & 0.000 \\
\hline Use public transportation (i.e., bus, subway or tram) & 864 & 2.685 & 2.650 & 2.727 & -0.639 & 0.523 \\
\hline $\begin{array}{l}\text { Adapt your dress style to meet the expectation of } \\
\text { local people at the destination }\end{array}$ & 865 & 3.088 & 3.336 & 2.796 & -5.756 & 0.000 \\
\hline $\begin{array}{l}\text { Go to places mostly locals go to (or very few tourists) } \\
\text { Eat local foods and specialties in locally owned }\end{array}$ & 866 & 3.143 & 3.225 & 3.048 & -2.522 & 0.012 \\
\hline $\begin{array}{c}\text { restaurant (instead of international food in known } \\
\text { branded places) }\end{array}$ & 867 & 3.421 & 3.448 & 3.389 & -0.528 & 0.598 \\
\hline Stay in your hotel to relax & 866 & 3.177 & 3.266 & 3.073 & -2.900 & 0.004 \\
\hline $\begin{array}{c}\text { Try using the local language (if not your } \\
\text { first language) }\end{array}$ & 864 & 2.865 & 3.047 & 2.650 & -4.466 & 0.000 \\
\hline Intentionally interact with locals & 866 & 3.155 & 3.220 & 3.078 & -1.958 & 0.050 \\
\hline $\begin{array}{l}\text { Does not keep the air conditioning or heater on when } \\
\text { you leave the room }\end{array}$ & 866 & 2.519 & 2.647 & 2.366 & -3.206 & 0.001 \\
\hline $\begin{array}{l}\text { Turn off the lights when you leave } \\
\text { your accommodation }\end{array}$ & 867 & 4.268 & 4.119 & 4.443 & -5.361 & 0.000 \\
\hline Bring and use a refillable water bottle & 867 & 3.518 & 3.406 & 3.649 & -3.084 & 0.002 \\
\hline Does not ask for a plastic bag when shopping & 865 & 2.413 & 2.543 & 2.259 & -3.256 & 0.001 \\
\hline Does not take more food than you needed at a buffet & 869 & 2.196 & 2.379 & 1.980 & -4.567 & 0.000 \\
\hline Does not take more than one shower per day & 865 & 2.155 & 2.331 & 1.947 & -4.727 & 0.000 \\
\hline Participate in your hotel's reuse towel program & 866 & 3.777 & 3.778 & 3.776 & -0.411 & 0.681 \\
\hline
\end{tabular}

Note. Construct questions pertaining to frugality, PEB and altruism were obtained from previous studies (see Holmes et al. [5]).

\subsection{Component Confirmation}

Prior to running the regression, each of the constructs were tested to ensure that their individual questions were able to measure the constructs satisfactorily. Given that each of the constructs have been previously tested (altruism $(26,39)$, frugality $(39)$, pro-ecological behaviour $(5,26)$, and sustainable travel behaviour $(5,33,40)$, each construct was verified through testing the Alphas, and removing items that improved the Alpha. The retained questions and subsequent Alphas can be seen in Table $4 \mathrm{a}-\mathrm{d}$ below.

Table 4. (a): Altruism Alphas. (b): Pro-Ecological Behaviour Alphas. (c): Frugality Alphas. (d): Past Sustainable Travel Behaviour Alphas.

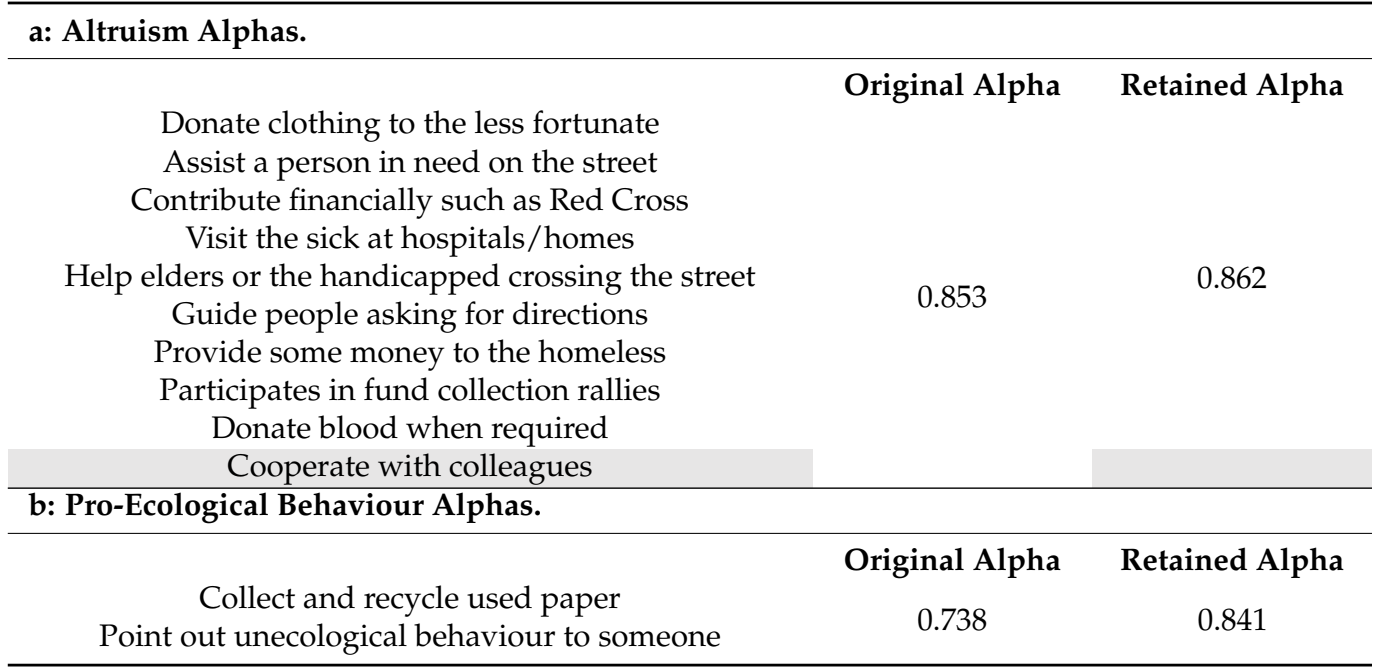


Table 4. Cont.

b: Pro-Ecological Behaviour Alphas.

Buy products in refillable packages

Original Alpha Retained Alpha Buy seasonal produce

Read about environmental issues

Talk with friends about environmental problems

Turn down air conditioning when leaving place

Look for ways to reuse things

Encourage friends and family to recycle

Conserve gasoline by walking or bicycling

Wait until have a full load before doing laundry

Do not use chemical insecticides (AI)

Drive on highway at speeds under $100 \mathrm{kph}$

Do not buy prepared food (AI)

Do not use clothes dryer (AI)

c: Frugality Alphas.

Do not buy a new car if old one is still functional

Original Alpha Retained Alpha

Wear the same clothing from a past season

Always eat meals at home

Rather walk than drive

Reuse notebooks and papers

Live lightly even when affording luxuries

Do not buy jewelry

Do not buy lots of shoes (AI)

Do not buy more food than needed (AI)

Do not use earnings for buying clothing (AI)

d: Past Sustainable Travel Behaviour Alphas.

Locally owned accommodations

Locally grown food and/or drink

Chain food (e.g., McDonalds)

Purchased Locally made arts and crafts

Look up a company's environmental or fair trade policy

Walk or cycle instead of taking motorized transportation

at the destination (taxi or renting a car)

Avoid renting a private car

Opt for a different destination that did not need flying to

Purchase carbon offsets to mitigate your carbon footprint

Use public transportation (i.e., bus, subway or tram)

Adapt your dress style to meet the expectation of local people at the destination

Go to places mostly locals go to (or very few tourists)

Eat local foods and specialties in locally owned

restaurant (instead of international food in known branded places)

Stay in your hotel to relax

Try using the local language (if not your first language)

Intentionally interact with locals

Does not ask for a plastic bag when shopping

Does not take more food than you needed at a buffet

Does not take more than one shower per day 
Table 4. Cont.

d: Past Sustainable Travel Behaviour Alphas.

Does not keep the air conditioning or heater on when you leave the room

Turn off the lights when you leave your accommodation Bring and use a refillable water bottle

Participate in your hotel's reuse towel program Greyed questions were omitted from the constructs.

\subsection{Results of Regression Analyses}

To test if the differences uncovered in the difference tests hold true when demographics are controlled for, a multi-step regression was undertaken (see Table 5). A hierarchical multi-step regression was run to understand the influence that demographics, travel characteristics, and everyday behaviour have on past sustainable travel behaviour (PSTB). The first model, looking at the influence of demographics was found to be significant and to show that females, older respondents, and the less educated were slightly less likely to travel sustainably than men, older respondents, and those with a graduate degree.

Model 2 adds travel characteristics to the model resulting in s a significant change to the $\mathrm{R}^{2}$. The second model finds those who revisit the same destination frequently and those who travel for leisure are less likely to travel sustainably. Model 2 also finds the more travel a respondent undertakes, the more sustainable their past travel behaviour has been in a destination.

Lastly, Model 3 looks at how everyday behaviour influences a tourist's sustainable travel behaviour. Model 3 derives the greatest explanatory power, accounting for 0.336 of the $\mathrm{R}^{2}$. Out of the three constructs, the scores with the greatest influence on sustainable travel behaviour are, in order of influence, altruism (0.333), frugality (0.216), and pro ecological behaviour (0.182). It is of note that, although the significance of its influence went from $p<0.01$ to $p<0.10$, travelling for business still had a positive influence on sustainable travel behaviour as compared to those who typically travel for leisure.

Table 5. Stepwise Regression.

\begin{tabular}{|c|c|c|c|c|c|c|c|c|c|}
\hline & \multicolumn{3}{|c|}{ Model 1-Demographics } & \multicolumn{3}{|c|}{$\begin{array}{l}\text { Model 2-Demographics + } \\
\text { Travel Characteristics }\end{array}$} & \multicolumn{3}{|c|}{$\begin{array}{c}\text { Model 3-Demographics + } \\
\text { Travel Characteristics }+ \\
\text { Everyday Behaviour }\end{array}$} \\
\hline & B & Std. Error & Sig & B & Std. Error & Sig & B & Std. Error & Sig \\
\hline $\begin{array}{l}\text { Female } \\
\text { Male }\end{array}$ & -0.021 & 0.012 & & -0.01 & 0.011 & & -0.03 & 0.008 & $* * *$ \\
\hline $\begin{array}{l}\text { Canadian Born } \\
\text { Not Canadian Born }\end{array}$ & -0.008 & 0.014 & & -0.015 & 0.014 & & -0.006 & 0.01 & \\
\hline 1928 to 1945 & -0.122 & 0.05 & * & -0.072 & 0.048 & & -0.073 & 0.035 & * \\
\hline 1946 to 1964 & -0.138 & 0.026 & $* * *$ & -0.093 & 0.025 & $* * *$ & -0.094 & 0.019 & $* * *$ \\
\hline 1965 to 1980 & -0.12 & 0.026 & $* * *$ & -0.078 & 0.025 & $* *$ & -0.069 & 0.018 & *** \\
\hline $\begin{array}{l}1981 \text { to } 1996 \\
1997 \text { to } 2020\end{array}$ & -0.033 & 0.026 & & -0.019 & 0.025 & & -0.019 & 0.018 & \\
\hline High School or Less & -0.051 & 0.018 & $* *$ & -0.03 & 0.017 & & -0.004 & 0.013 & \\
\hline College Diploma & -0.062 & 0.017 & $* * *$ & -0.043 & 0.016 & $* *$ & -0.017 & 0.012 & \\
\hline $\begin{array}{l}\text { University Degree } \\
\text { Graduate Degree }\end{array}$ & -0.052 & 0.015 & $* *$ & -0.039 & 0.014 & $* *$ & -0.026 & 0.01 & * \\
\hline$<\$ 30,000$ & -0.067 & 0.024 & $* *$ & -0.064 & 0.023 & $* *$ & -0.029 & 0.017 & \\
\hline$\$ 30,000-\$ 49,999$ & -0.024 & 0.023 & & -0.018 & 0.023 & & 0 & 0.017 & \\
\hline$\$ 50,000-\$ 69,999$ & -0.035 & 0.023 & & -0.036 & 0.022 & & -0.013 & 0.016 & \\
\hline$\$ 70,000-\$ 99,999$ & -0.019 & 0.022 & & -0.017 & 0.021 & & 0.002 & 0.015 & \\
\hline
\end{tabular}


Table 5. Cont.

\begin{tabular}{|c|c|c|c|c|c|c|c|c|c|}
\hline & \multicolumn{3}{|c|}{ Model 1-Demographics } & \multicolumn{3}{|c|}{$\begin{array}{l}\text { Model 2-Demographics + } \\
\text { Travel Characteristics }\end{array}$} & \multicolumn{3}{|c|}{$\begin{array}{c}\text { Model 3-Demographics + } \\
\text { Travel Characteristics }+ \\
\text { Everyday Behaviour }\end{array}$} \\
\hline & B & Std. Error & Sig & B & Std. Error & Sig & B & Std. Error & Sig \\
\hline $\begin{array}{c}\$ 100,000-\$ 149,999 \\
\$ 150,000+ \\
\text { Alone }\end{array}$ & -0.045 & 0.021 & * & -0.041 & 0.02 & * & -0.01 & 0.014 & \\
\hline Partner/Spouse & & & & 0.026 & 0.015 & & 0.011 & 0.011 & \\
\hline Family & & & & 0.01 & 0.017 & & 0.012 & 0.013 & \\
\hline Friends & & & & 0.012 & 0.025 & & 0.007 & 0.018 & \\
\hline Colleagues & & & & -0.026 & 0.019 & & -0.017 & 0.014 & \\
\hline Other & & & & -0.063 & 0.092 & & -0.098 & 0.067 & \\
\hline Winter & & & & 0.026 & 0.017 & & 0.018 & 0.012 & \\
\hline Spring & & & & 0.02 & 0.019 & & 0.037 & 0.014 & $* *$ \\
\hline Summer & & & & 0.024 & 0.014 & & 0.029 & 0.01 & $* *$ \\
\hline Fall & & & & 0.033 & 0.023 & & 0.03 & 0.017 & \\
\hline All Seasons & & & & & & & & & \\
\hline Repeat Never & & & & 0.054 & 0.017 & $* *$ & 0.029 & 0.013 & * \\
\hline Repeat Sometimes & & & & 0.048 & 0.015 & $* *$ & 0.026 & 0.011 & * \\
\hline Repeat Frequently & & & & & & & & & \\
\hline Domestic Travel & & & & 0.001 & 0.001 & * & 0.001 & 0 & \\
\hline International Travel & & & & 0.002 & 0.001 & $* * *$ & 0.001 & 0 & $* * *$ \\
\hline $\begin{array}{l}\text { Typically Travel } \\
\text { for Business }\end{array}$ & & & & 0.038 & 0.014 & $* *$ & 0.019 & 0.01 & \\
\hline $\begin{array}{l}\text { Typically Travel } \\
\text { for Leisure }\end{array}$ & & & & & & & & & \\
\hline Altruism & & & & & & & 0.333 & 0.029 & $* * *$ \\
\hline $\begin{array}{l}\text { Pro Ecological } \\
\text { Behaviour }\end{array}$ & & & & & & & 0.182 & 0.036 & $* * *$ \\
\hline Frugality & & & & & & & 0.216 & 0.034 & $* * *$ \\
\hline $\begin{array}{l}\text { (Constant)_-Past } \\
\text { Sustainable Travel } \\
\text { Behaviour }\end{array}$ & 0.728 & 0.032 & $* * *$ & 0.566 & 0.037 & $* * *$ & 0.098 & 0.035 & $* *$ \\
\hline R-square Change & & $0.155^{* * *}$ & & & $0.128^{* * *}$ & & & $0.336^{* * *}$ & \\
\hline Adjusted R-square & & 0.135 & & & 0.248 & & & 0.599 & \\
\hline
\end{tabular}

Italics identifies omitted variable; ${ }^{* * *}$ significant at the 0.001 level; ${ }^{* *}$ significant at the 0.01 level; ${ }^{*}$ significant at the 0.05 level.

Beyond looking at the overall explanatory power of each step in the regression influencing the prediction power of the model, separate regressions were run for business and leisure travellers to see if there were differences in the predictive power of the everyday behaviours (PEB, altruism, frugality). Altruism was found to be a significant predictor of sustainable travel behaviour (STB) for both business and leisure travellers, supporting Hypotheses 4 and 5 (see Table 6). While pro-ecological behaviour and frugality at home positively influence STB, supporting Hypotheses 2 and 3, PEB has a larger influence on leisure travellers, while frugality plays a larger role for business travellers.

Table 6. Regression Results by Respondent Type.

\begin{tabular}{|c|c|c|c|c|c|c|c|c|c|}
\hline & \multicolumn{3}{|c|}{ All Respondents } & \multicolumn{3}{|c|}{ Business Travellers } & \multicolumn{3}{|c|}{ Leisure Travellers } \\
\hline & B & Std. Error & Sig & B & Std. Error & Sig & B & Std. Error & Sig \\
\hline $\begin{array}{l}\text { Female } \\
\text { Male }\end{array}$ & -0.030 & 0.008 & $* * *$ & -0.041 & 0.012 & ** & -0.016 & 0.012 & \\
\hline $\begin{array}{l}\text { Canadian Born } \\
\text { Not Canadian Born }\end{array}$ & -0.006 & 0.010 & & -0.010 & 0.015 & & -0.007 & 0.014 & \\
\hline
\end{tabular}


Table 6. Cont.

\begin{tabular}{|c|c|c|c|c|c|c|c|c|c|}
\hline & \multicolumn{3}{|c|}{ All Respondents } & \multicolumn{3}{|c|}{ Business Travellers } & \multicolumn{3}{|c|}{ Leisure Travellers } \\
\hline & B & Std. Error & Sig & B & Std. Error & Sig & B & Std. Error & Sig \\
\hline 1928 to 1945 & -0.073 & 0.035 & $*$ & -0.087 & 0.053 & & -0.087 & 0.048 & \\
\hline 1946 to 1964 & -0.094 & 0.019 & $* * *$ & -0.086 & 0.030 & $* *$ & -0.107 & 0.024 & $* * *$ \\
\hline 1965 to 1980 & -0.069 & 0.018 & $* * *$ & -0.059 & 0.029 & * & -0.085 & 0.024 & $* * *$ \\
\hline 1981 to 1996 & -0.019 & 0.018 & & -0.007 & 0.029 & & -0.047 & 0.024 & $*$ \\
\hline 1997 to 2020 & & & & & & & & & \\
\hline High School or Less & -0.004 & 0.013 & & -0.001 & 0.019 & & -0.007 & 0.019 & \\
\hline College Diploma & -0.017 & 0.012 & & -0.020 & 0.016 & & -0.007 & 0.018 & \\
\hline University Degree & -0.026 & 0.010 & * & -0.038 & 0.013 & $* *$ & -0.006 & 0.017 & \\
\hline \multicolumn{10}{|l|}{ Graduate Degree } \\
\hline$<\$ 30,000$ & -0.029 & 0.017 & & -0.022 & 0.025 & & -0.029 & 0.028 & \\
\hline$\$ 30,000-\$ 49,999$ & 0.000 & 0.017 & & -0.016 & 0.023 & & 0.006 & 0.028 & \\
\hline$\$ 50,000-\$ 69,999$ & -0.013 & 0.016 & & -0.030 & 0.020 & & -0.004 & 0.029 & \\
\hline$\$ 70,000-\$ 99,999$ & 0.002 & 0.015 & & -0.008 & 0.020 & & 0.013 & 0.028 & \\
\hline$\$ 100,000-\$ 149,999$ & -0.010 & 0.014 & & -0.022 & 0.017 & & 0.007 & 0.027 & \\
\hline \multicolumn{10}{|l|}{$\$ 150,000+$} \\
\hline \multicolumn{10}{|l|}{ Alone } \\
\hline Partner/Spouse & 0.011 & 0.011 & & 0.013 & 0.014 & & -0.018 & 0.018 & \\
\hline Family & 0.012 & 0.013 & & 0.027 & 0.019 & & -0.017 & 0.020 & \\
\hline Friends & 0.007 & 0.018 & & 0.021 & 0.035 & & -0.022 & 0.025 & \\
\hline Colleagues & -0.017 & 0.014 & & -0.009 & 0.015 & & -0.011 & 0.094 & \\
\hline Other & -0.098 & 0.067 & & 0.059 & 0.099 & & -0.285 & 0.095 & $* *$ \\
\hline Winter & 0.018 & 0.012 & & 0.034 & 0.020 & & 0.005 & 0.016 & \\
\hline Spring & 0.037 & 0.014 & $* *$ & 0.041 & 0.018 & * & 0.014 & 0.023 & \\
\hline Summer & 0.029 & 0.010 & $* *$ & 0.041 & 0.014 & $* *$ & 0.003 & 0.014 & \\
\hline Fall & 0.030 & 0.017 & & 0.043 & 0.031 & & 0.019 & 0.020 & \\
\hline \multicolumn{10}{|l|}{ All Seasons } \\
\hline Repeat Never & 0.029 & 0.013 & * & 0.042 & 0.018 & * & 0.000 & 0.019 & \\
\hline Repeat Sometimes & 0.026 & 0.011 & * & 0.025 & 0.015 & & 0.005 & 0.019 & \\
\hline \multicolumn{10}{|l|}{ Repeat Frequently } \\
\hline Domestic Travel & 0.001 & 0.000 & & 0.001 & 0.001 & & 0.000 & 0.001 & \\
\hline International Travel & 0.001 & 0.000 & $* * *$ & 0.001 & 0.001 & & 0.002 & 0.001 & $* *$ \\
\hline $\begin{array}{l}\text { Typically Travel } \\
\text { for Business }\end{array}$ & 0.019 & 0.010 & & & & & & & \\
\hline \multicolumn{10}{|l|}{ Typically Travel for Leisure } \\
\hline Altruism & 0.333 & 0.029 & $* * *$ & 0.388 & 0.039 & $* * *$ & 0.257 & 0.044 & $* * *$ \\
\hline Pro Ecological Behaviour & 0.182 & 0.036 & $* * *$ & 0.152 & 0.051 & $* *$ & 0.228 & 0.053 & $* * *$ \\
\hline Frugality & 0.216 & 0.034 & $* * *$ & 0.246 & 0.046 & $* * *$ & 0.159 & 0.050 & $* *$ \\
\hline (Constant)_Past & & & & & & & & & \\
\hline $\begin{array}{c}\text { Sustainable Travel } \\
\text { Behaviour }\end{array}$ & 0.098 & 0.035 & $* *$ & 0.080 & 0.048 & & 0.205 & 0.058 & $* * *$ \\
\hline Adjusted R-square & & 0.599 & & & 0.644 & & & 0.486 & \\
\hline
\end{tabular}

Italics identifies omitted variable; ${ }^{* * *}$ significant at the 0.001 level; ${ }^{* *}$ significant at the 0.01 level; ${ }^{*}$ significant at the 0.05 level.

In summary, three of the five hypotheses were found to be supported. Supporting Hypotheses 1, business and leisure travellers were found to differ in their sustainable travel behaviour, with business travellers being more sustainable when travelling overall. In regard to Hypotheses 2 and 3, while it was thought that frugality might have only been a predictor of sustainable travel behaviour for leisure travellers, it was also found to be a predictor for business travellers. Lastly, altruism was found to be a significant predictor of sustainable travel behaviour (STB) for both business and leisure travellers, supporting Hypothesis 4 and 5. 


\section{Discussion and Conclusions}

Prior work has found factors of demographics, travel behaviour, and everyday behaviour to influence sustainable travel behaviour. This research found demographics to still be an indicator of sustainable travel behaviour. Educated millennial travellers were found to be more sustainable which support past studies [5,41]. Travel characteristics were also found to add a modicum of explanatory power, finding that those who typically do not revisit the same destination and / or who travel more frequently, are more likely to travel sustainably. This suggests that travel destinations should look to target the well-travelled tourist in an attempt to attract those who travel more sustainably which supports in part Dodds's [42] theory of tourism experience is linked to sustainable travel.

While previous studies have questioned or found everyday behaviour to be the greatest indicator of sustainable travel $[5,10,43]$, they have treated all travellers as a homogeneous group. Beyond confirming that everyday behaviour still has the greatest explanatory power for predicting sustainable travel behaviour, this study looked to investigate differences between leisure and business travellers. Focusing on Canadian travellers, and segmenting them based on their typical travel for business or leisure, this study found that business travellers tend to travel more sustainably than those who travel for leisure. This may be a result of businesses requiring sustainable travel as part of their company's policies. Further, this research found altruistic tendencies of travellers when at home to be the largest predictor of their sustainable behaviours when travelling. As such, DMOs should look to better understand their target market through tourist segmenting and market research, to attract those who are more altruistic in their everyday behaviour.

\subsection{Conclusions}

This research has three primary outcomes. First, this research found that business travellers are more likely to travel sustainably, which may suggest that businesses have an influence on sustainable travel behaviour. For this benefit to be realized and improved, there is a need to augment or increase corporate responsibility efforts within travel policies. Further, businesses need to be made aware of this relationship so that they can see the influence that they are having. Second, there needs to be more research into business travel and the influence businesses can have. For industry to also benefit from this research, this work needs to be disseminated through both academic and industry outlets. Lastly, the majority of work in this area is lacking, as most research either focuses on the leisure tourist or treats all tourists as a homogeneous group; therefore, there is a missed opportunity to understand the differences between sustainable travel behaviour of leisure and business travellers independent of each other. By better understanding the differences between the markets and the factors that attract them and drive them to travel sustainably, destinations can look to target those travellers who look to not only visit the destination but to undertake such visitation in a sustainable way.

\subsection{Limitations and Future Research}

This paper has a few limitations and suggests a number of recommendations. This study surveyed only Canadian travellers; as such, future research to look to expand the sample population to incorporate other countries and cultures to investigate if these findings hold true. Survey respondents in this study were asked to reflect on, and answer questions pertaining to their past travel experience, which may have been influenced by their ability to recall experiences that were further out. Future research should look to implement a two-stage process: first, asking respondents to answer questions pertaining to everyday behaviour, and second, asking participants to answer questions pertaining to their travel during their trip or upon return. Future research would also benefit from incorporating qualitative interviews that provide greater explanation for why everyday behaviour translates into sustainable travel behaviour. Lastly, future research could investigate how specific business policies and types influence employee travel behaviour and 
the mediating and/or moderating role they may play between their employees everyday behaviours and sustainable travel outcomes.

Author Contributions: Conceptualization, R.D. and M.R.H.; literature review, R.D.; methodology, M.R.H. and R.D.; validation, M.R.H.; formal analysis, M.R.H. and R.D.; investigation, R.D. and M.R.H.; resources, R.D. and M.R.H.; data curation, M.R.H.; writing—original draft preparation, R.D. and M.R.H.; writing—review and editing, R.D. and M.R.H.; project administration, R.D. and M.R.H. All authors have read and agreed to the published version of the manuscript.

Funding: This research received no external funding.

Institutional Review Board Statement: The study was conducted according to the guidelines of the Declaration of Helsinki, and approved by the Institutional Review Board (or Ethics Committee) of Ryerson University (protocol code 2017-135-2, 19 November 2019).

Informed Consent Statement: Informed consent was obtained from all subjects involved in the study.

Data Availability Statement: The data presented in this study are available on request from the corresponding author.

Conflicts of Interest: The authors declare no conflict of interest.

\section{References}

1. Gehlert, T.; Dziekan, K.; Gärling, T. Psychology of sustainable travel behavior. Transp. Res. Part A Policy Pract. 2013, 48, 19-24. [CrossRef]

2. Liu, A.; Ma, E.; Qu, H.; Ryan, B. Daily green behavior as an antecedent and a moderator for visitors' pro-environmental behaviors. J. Sustain. Tour. 2020, 28, 1390-1408. [CrossRef]

3. Buffa, F. Young tourists and sustainability. profiles, attitudes, and implications for destination strategies. Sustainability 2015, 7 , 14042-14062. [CrossRef]

4. Dodds, R.; Graci, S.R.; Holmes, M. Does the tourist care? A comparison of tourists in Koh Phi Phi, Thailand and Gili Trawangan, Indonesia. J. Sustain. Tour. 2010, 18, 207-222. [CrossRef]

5. Holmes, M.R.; Dodds, R.; Frochot, I. At home or abroad, does our behavior change? Examining how everyday behavior influences sustainable travel behavior and tourist clusters. J. Travel Res. 2021, 60, 102-116. [CrossRef]

6. Nickerson, N.P.; Jorgenson, J.; Boley, B.B. Are sustainable tourists a higher spending market? Tour. Manag. 2016, 54, 170-177. [CrossRef]

7. Pulido-Fernández, J.; López-Sánchez, Y. Are tourists really willing to pay more for sustainable destinations? Sustainability 2016, 8, 1240. [CrossRef]

8. Budeanu, A. Sustainable tourist behaviour-A discussion of opportunities for change. Int. J. Consum. Stud. 2007, 31, 499-508. [CrossRef]

9. Gössling, S. Tourism, tourist learning and sustainability: An exploratory discussion of complexities, problems and opportunities. J. Sustain. Tour. 2018, 26, 292. [CrossRef]

10. Juvan, E.; Dolnicar, S. The attitude-behaviour gap in sustainable tourism. Ann. Tour. Res. 2014, 48, 76-95. [CrossRef]

11. Miller, D.; Merrilees, B.; Coghlan, A. Sustainable urban tourism: Understanding and developing visitor pro-environmental behaviours. J. Sustain. Tour. 2015, 23, 26-46. [CrossRef]

12. Oliver, J.; Benjamin, S.; Leonard, H. Recycling on vacation: Does pro-environmental behavior change when consumers travel? J. Glob. Sch. Mark. Sci. 2019, 29, 266-280. [CrossRef]

13. Verma, V.K.; Chandra, B.; Kumar, S. Values and ascribed responsibility to predict consumers' attitude and concern towards green hotel visit intention. J. Bus. Res. 2019, 96, 206-216. [CrossRef]

14. Madrigal, R. Personal values, traveler personality type, and leisure travel style. J. Leis. Res. 1995, 27, 125-142. [CrossRef]

15. Han, H.; Yu, J.; Koo, B.; Kim, W. Vacationers' norm-based behavior in developing environmentally sustainable cruise tourism. J. Qual. Assur. Hosp. Tour. 2019, 20, 89-106. [CrossRef]

16. Cohen, S.A.; Hanna, P.; Gössling, S. The dark side of business travel: A media comments analysis. Transp. Res. Part D Transp. Environ. 2018, 61, 406-419. [CrossRef]

17. Walsh, P.R.; Dodds, R.; Priskin, J.; Day, J.; Belozerova, O. The Corporate Responsibility Paradox: A Multi-National Investigation of Business Traveller Attitudes and Their Sustainable Travel Behaviour. Sustainability 2021, 13, 4343. [CrossRef]

18. Whitmarsh, L.; O'Neill, S. Green identity, green living? The role of pro-environmental self-identity in determining consistency across diverse pro-environmental behaviours. Identity Place Environ. Behav. 2010, 30, 305-314. [CrossRef]

19. Hibbert, J.F.; Dickinson, J.E.; Gössling, S.; Curtin, S. Identity and tourism mobility: An exploration of the attitude-behaviour gap. J. Sustain. Tour. 2013, 21, 999-1016. [CrossRef] 
20. Yamoah, F.A.; Acquaye, A. Unravelling the attitude-behaviour gap paradox for sustainable food consumption: Insight from the UK apple market. J. Clean. Prod. 2019, 217, 172-184. [CrossRef]

21. Sawitri, D.R.; Hadiyanto, H.; Hadi, S.P. Pro-environmental behavior from a socialcognitive theory perspective. Procedia Environ. Sci. 2015, 23, 27-33. [CrossRef]

22. Corral-Verdugo, V.; Mireles-Acosta, J.F.; Tapia-Fonllem, C.; Fraijo-Sing, B. Happiness as correlate of sustainable behavior: A study of pro-ecological, frugal, equitable and altruistic actions that promote subjective wellbeing. Hum. Ecol. Rev. 2011, 18, 95-104.

23. Corral-Verdugo, V.; Tapia-Fonllem, C.; Ortiz-Valdez, A. On the relationship between character stren.gths and sustainable behavior. Environ. Behav. 2015, 47, 877-901. [CrossRef]

24. Tapia-Fonllem, C.; Corral-Verdugo, V.; Gutiérrez-Sida, C.; Mireles-Acosta, J.; Tirado-Medina, H. Emotions and pro-environmental behaviour. In Psychological Approaches to Sustainability: Current Trends in Theory, Research and Applications; Nova Science Publishers: Hauppauge, NY, USA, 2013.

25. Barbaro, N.; Pickett, S.M. Mindfully green: Examining the effect of connectedness to nature on the relationship between mindfulness and engagement in pro-environmental behavior. Personal. Individ. Differ. 2016, 93, 137-142. [CrossRef]

26. Corral-Verdugo, V.; García, C.; Castro, L.; Viramontes, I.; Limones, R. Equity and sustainable lifestyles. In Psychological Approaches to Sustainability; Corral-Verdugo, V., García, C., Frías, M., Eds.; Nova Science Publishers: New York, NY, USA, 2010.

27. Craig, T.P.; Fischer, A.; Lorenzo-Arribas, A. Shopping versus Nature? An Exploratory Study of Everyday Experiences. Front. Psychol. 2018, 9, 9. [CrossRef]

28. Hoot, R.E.; Friedman, H. Connectedness and environmental behavior: Sense of interconnectedness and pro-environmental behavior. J. Transpers. Stud. 2010, 30, 89-100.

29. Panda, T.K.; Kumar, A.; Jakhar, S.; Luthra, S.; Garza-Reyes, J.A.; Kazancoglu, I.; Nayak, S.S. Social and environmental sustainability model on consumers' altruism, green purchase intention, green brand loyalty and evangelism. J. Clean. Prod. 2020, 243, 118575. [CrossRef]

30. Han, H.; Yu, J.; Kim, W. Youth travelers and waste reduction behaviors while traveling to tourist destinations. J. Travel Tour. Mark. 2018, 35, 1119-1131. [CrossRef]

31. Kim, M.-S.; Stepchenkova, S. Altruistic values and environmental knowledge as triggers of pro-environmental behavior among tourists. Curr. Issues Tour. 2020, 23, 1575-1580. [CrossRef]

32. Young, W.; Davis, M.; McNeill, I.M.; Malhotra, B.; Russell, S.; Unsworth, K.; Clegg, C.W. Changing behaviour: Successful environmental programmes in the workplace. Bus. Strategy Environ. 2015, 24, 689-703. [CrossRef]

33. Juvan, E.; Dolnicar, S. Measuring environmentally sustainable tourist behaviour. Ann. Tour. Res. 2016, 59, 30-44. [CrossRef]

34. Fehr, E.; Fischbacher, U. The nature of human altruism. Nature 2003, 425, 785-791. [CrossRef]

35. Piliavin, J.A.; Charng, H.-W. Altruism: A review of recent theory and research. Annu. Rev. Sociol. 1990, 16, 27-65. [CrossRef]

36. Schultz, P.W. The Structure of Environmental Concern: Concern for Self, Other People, and the Biosphere. J. Environ. Psychol. 2001, 21, 327-339. [CrossRef]

37. Mayer, F.S.; Frantz, C.M. The connectedness to nature scale: A measure of individuals' feeling in community with nature. J. Environ. Psychol. 2004, 24, 503-515. [CrossRef]

38. Canavan, B. An existentialist exploration of tourism sustainability: Backpackers fleeing and finding themselves. J. Sustain. Tour 2018, 26, 551-566. [CrossRef]

39. Corral-Verdugo, V.; García, F.I.; Tapia-Fonllem, C.; Fraijo-Sing, B. Sustainable behaviors and perceived psychological restoration. Acta De Investig. Psicológica-Psychol. Res. Rec. 2012, 2, 749-764. [CrossRef]

40. Passafaro, P.; Cini, F.; Boi, L.; D’Angelo, M.; Heering, M.S.; Luchetti, L.; Mancin, A. The "sustainable tourist": Values, attitudes, and personality traits. Tour. Hosp. Res. 2015, 15, 225-239. [CrossRef]

41. Cavagnaro, E.; Staffieri, S.; Carrieri, A.; Burns, K.; Chen, N.; Fermani, A. Profiling for sustainable tourism: Young travellers' self-transcendence values and motivations. Eur. J. Tour. Res. 2021, 28, 2810.

42. Dodds, R. The tourist experience life cycle: A perspective article. Tour. Rev. 2019, 75, 216-220. [CrossRef]

43. Ramchurjee, N.A.; Suresha, S. Are tourists' environmental behavior affected by their environmental perceptions and beliefs? J. Environ. Tour. Anal. 2015, 3, 26. 